munities, the density of animal populations and the yield of living material from the areas studied: a main problem has been that of the soils of a vegetation complex at Moel Eilio in the Conway Valley, where a mosaic of brown earths and peaty podzols occurs. The study and characterization of clay minerals of Snowdonian soil clays has continued, with particular emphasis on those derived from pumice tuff, and an investigation has been started on the mineral nutrient turnover in selected mountain grassland ecosystems, as well as a long-term investigation into the effects of different sheep-population densities on the productivity of a mountain grassland community at Cwm Dyli.

In conservation a new co-operative approach was made to the chronio problems of the Norfolk and Suffolk Broads and a similar type of approach is being made to the prob. lems of the Breckland and of the Purbeck area. With the approval of the management plan for Knocking Hoe and the revised plan for Roudsea Wood, 29 out of the 52 English reserves are now managed on approved plans, 24 out of 29 Scottish reserves and 10 out of 24 Welsh reserves. Revised lists of notified 'sites of special scientific interest' were approved for Cumberland, Lancashire, Glamorgan, Monmouthshire, Breconshire, Flintshire and Montgomeryshire. However, reference is made in the report to the danger which service requirements offer to several such sites, as well as to the concern for the New Forest and other areas arising from large-scale pollution from the proposed 2,000-MW power station at Fawley.
The reports on the conservation work in different parts of Britain contain much of scientific interest and this is no less true of the work of the Scientific Advisory Services. Some reference has been made elsewhere to this work in respect of toxic chemicals and water resources (see Nature, 201, 954; 1964), and the value of this work is further illustrated in the Conservancy's second major scientific monograph, The Geology of Moor House: a National Nature Reserve in North-East Westmorland, issued in February 1963 (Nature, 199, 941; 1963), and in work with regard to the protection of birds: it was on the Conservancy's advice that the Home Office decided that oyster-catchers should not be controlled by shooting unless common-netting failed.

The report includes some account of the Conservancy's educational work, including the successful conferences to discuss proposals for the experimental use of Ainsdale Sand Dunes as an educational nature reserve: a section on international and overseas activities indicates the growing extent of such spheres of action. The Conservancy is called on to participate in such programmes as the African Special Project of the International Union for Conservation of Nature and Natural Resources, the European and North African Marshlands project and the planning of the International Biological Programme. The Conservancy is also represented on a Committee of Experts for the Conservancy of Nature and landscape, which was set up by the Council of Europe.

\title{
SCIENCE IN LOCAL GOVERNMENT
}

$\mathrm{T}^{\mathrm{H}}$ HE growing demand for scientific advice in local government has essentially been brought about by four major factors: (1) new materials arising from industrial development; (2) increasing appreciation on the part of responsible local government officials of the assistance that the scientist can give; (3) the availability of now methods for detecting harmful contaminants and assessing quality; (4) the use of methods based on modern techniques in place of traditional ones. That this is so is well demonstrated by the ennual report for 1962 of the Scientific Adviser to the London County Council*.

The report deseribes the work of the Scientific Branch of the Public Health Department, the services of which have now been made available to the Metropolitan borough eouncils. Moreover, on the retirement of their public analyst, two of those boroughs have arranged for the food and drugs analysis work to be transferred to the Council's laboratories, and a public analyst has been appointed for these duties as well as the work on food and drug purchases by the Council. The staff of the Branch now totals 99 , including 38 graduates, 54 ancillary staff and 7 in a clerical section: a list of scientific staff is attached to the report. Samples handled reached a record of 66,463 . Many analytical reports entailed no laboratory work, and besides attendance at scientific committees and the preparations of specifications, the staff was called on for work on new methods of analysis and new equipment.

The work of the Scientific Branch of the Council's Public Health Department is carried out at the head. quarters laboratories at the County Hall and in laboratories at the Northern and Southern Outfall Works at Beckton and Crossness, respectively. Some 22,265 airsafety tests were made at the Northern Outfall Works Laboratory, where investigations were made in the possible use of an industrial sludge and into the efficiency of the precipitron filters at the power house; and a gas chromatograph was constructed to use a katharometer of

- London County Council. Public Health Department: Scientifle Branch. Annunl Report of the Scientifis, Adviser, 1962. Pp. $78+4$ plates. (London L. Idon County Counoll, 1963.) the 'Pretzel' cell type for detecting methane. A survey was also made of methods for determining nitrate in effluents. At the Southern Outfall Works Laboratory, dissolved oxygen and sulphide relations in Thames water were investigated, and, besides the attention regularly given to the condition of the Thames, waters from tributaries of the Thames were regularly examined by the Branch.

Much attention was given to paints and building materials, while besides foodstuffs generally, including tender samples, deliveries and complaints, specimen meals served to school children were analysed to enable the organizers to check the nutrient values. Regular observations were made of the degree of air pollution at 23 sites, and investigation of the concentration of sulphur dioxide at a sixth-floor flat $140 \mathrm{ft}$. from the chimney of $a$ boiler house showed a concentration of 55 per cent above the 'smog'-level during at least 40 per cent of a five-day period when the wind was in the right direction. The building of tall bloeks within range of power-station chimneys thus presents a special problem and more information is needed. Methods for detecting and measuring traces of radioactive matter were further developed, and the Branch co-operates with other departments to ensure efficient water treatment in the Council's bathing ponds and swimming pools, while weekly tests were made of the atmospheric conditions in Blackwall and Rotherhithe Tunnels when the Tunnels were carrying heavy traffic.

Work was extensively undertaken for the London Fire Brigade, and fabrics were tested for flame-proof properties, wall-surface materials for the rate of flame-spread and rubber hose for its quality and suitability for use in the fire service. Besides regular examination of samples from steam-raising plants, the use of 'Calgon' or 'Mieromet' for inhibiting scale-formation in domestic hot-water systems continued with satisfactory results. Dosing hotwater heating systems with dichlorophen at 20 p.p.m. proved completely successful in destroying colonies of sulphate-reducing organisms in both small and large 
heating installations, and in ensuring circulation troubles due to gas-blocking and blockage of pipes by sludge. Some research was undertaken for improving products manufactured to the Council's specifications, such as a laundry powder for white work at large laundries and a detergent for use in washing-up machines. The assessment of traffic noise has become a principal task of the Physics Section.

\section{MANAGERS AND SHOP STEWARDS}

\begin{abstract}
A
FURTHER occasional paper from the Institute of Personnel Management, which is entitled Managers and Shop Stewards*, gives a balanced but concise account of the problems presented in industry by the rise of the shop steward-a phenomenon which reinforces much of the argument to-day for more attention to management and industrial training generally, including the education of the shop stewards themselves. There are also ample notes and references.

In the first chapter, Mr. Marsh reviews the growth of workplace bargaining as he describes the essentially domestic issues of a works or factory with which the shop steward is concerned, pointing out that the shop stewards as we know them to-day, except in the printing industry and in some engineering firms, date only from the early 1940's. He explains the work of the shop stewards and the inevitability of some form of workplace bargaining, quite apart from outside agreements, for managements which desire close relations with their workers on a domestic basis. In the second chapter he discusses the advantages and disadvantages which workplace bargaining presents for the Unions and the solutions which the Trade Unions could offer. He points out that, in Trade Unions, rules and discipline are not related in any simple way and that Unions rules form only part of the system of regulations under which shop stewards operate; other kinds of rules may be more important than those provided by the Unions themselves. Both Unions and

* Institute of Personnel Management. Managers and Shop Stewards. By Arthur Marsh. Pp. 40. (London: Institute of Personnel Management,
1963.) $78.6 d$.
\end{abstract}

employers are conscious that the greatest force for control within any Union is not the rules themselves but the relation of workplace representatives with full-time officials, and Mr. Marsh insists that while there can be strong Unions there cannot be good relations without good employers.

Mr. Marsh then examines in his third chapter the advantages and problems of workplace bargaining for management and the solutions which management could offer, stressing particularly that management should show more initiative in this field to ensure that the rules under which bargaining is conducted are understandable and predictable. Finally, in his last chapter on the future of workplace bargaining, he considers the challenge which the evolution of this system presents, the reasons which have led both Unions and employers to favour the growth of educational provision for both management and shop stewards in the field of industrial relations in the workplace. This he regards as a major challenge to the teaching capacity of managements, Unions, technical colleges and extra-mural educational bodies like the Workers Educational Association and the universities. While that is a long-term contribution, the heaviest and primary responsibility lies with management, not because managements are often wrong, but because they cannot afford the luxury of 'not being right', and Mr. Marsh suggests in conclusion that the responsibilities of managers under workplace bargaining are so onerous that they would be wise to act as if it were true that managements get the shop stewards they deserve.

\section{LEARNING TO READ}

T HREE papers recently published in Educational Research (6, No. 1; November 1963. Published for the National Foundation for Educational Research by Newnes Educational Publishing Co., Ltd.) deal with the concept of reading readiness which has prevailed in English-speaking countries over the past fow decades, during which it has been widely held that a child is not ready to learn to read until he has attained a mental age of about $6 \frac{1}{2}$. A. E. Sanderson feels that this concept is in urgent need of re-examination since nation-wide literacy is possible only in an environment exerting social and economic pressure on children to acquire and use reading habits and skills. The concept implies that children reach the stage of reading readiness at different chronological ages, and that the teacher is in a position to give individual attention to each child. On the other hand, the risk of frustration and of the development of actual resistance to reading can be avoided by not pressing children to begin too soon.

If reading readiness depends on mental age, some kind of test would seem to be necessary to establish it in the case of each child. In the classroom, however, that is impracticable, and most teachers say that they know by 'instinct' when the appropriate time has arrived. In this respect, indications suggest that parents are taking less interest in their children's reading than in former times: even so, clashes between schools and parents' ambitions for their children are by no means uncommon, while the best results are obtained when there is active co-operation between school and home.

R. Lynn relates reading readiness to the process of mental maturation, which, in the minds of many people, is a biological phenomenon that cannot be speeded up; and a good many observers hold that before the mental age of 6-8 a child is capable of recognizing simple outline figures but not matters of detail. Lynn considers that statements like these underrate children's capacity for perception, particularly since it has been shown that they can distinguish between nonsense letters, like squares, triangles and irregular shapes, at a mental age of $4-4 \frac{1}{2}$. He quotes a number of cases of children who have taken the first steps in reading as early as 16-18 months, the record for this apparently being held by Francis Galton, who could recognize all the capital letters when only one year old. In two of these cases, however, the children lost interest in reading soon after they had begun.

A fairly common difficulty which children experienco is in distinguishing between reversals ( $n$ and $u$ ) and be. tween mirror images $(d$ and $b$ ). It has been shown that certain animals, such as rats and octopuses, have trouble of the same kind. With ehildren, there is some evidence that this problem may be capable of solution through practice under suitable care.

To J. A. Downing the question, should we, is separate from that of can we teach children of young age to read. $\mathrm{He}$ believes that the problem-solving schemata of 